\title{
Human Platelet-derived Growth Factor Stimulates Prostaglandin Synthesis by Activation and by Rapid De Novo Synthesis of Cyclooxygenase
}

\author{
Andreas J. R. Habenicht, Matthias Goerig, Jürgen Grulich, Dietrich Rothe, Rainer Gronwald, Ulrike Loth, \\ Gotthard Schettler, Burghard Kommerell, and Russell Ross \\ University of Heidelberg, Medical School, D-6900 Heidelberg, Federal Republic of Germany; University of Washington, \\ School of Medicine, Department of Pathology, Seattle, Washington 98195
}

\begin{abstract}
Human platelet-derived growth factor (PDGF) stimulated prostaglandin (PG) $E_{2}$ synthesis in the cell cycle of Swiss $3 T 3$ cells at two distinct time intervals, with a first plateau within $10 \mathrm{~min}$ and a second plateau within 2-4 h after addition of PDGF. At $4 \mathrm{~h}$, the concentration of $\mathrm{PGE}_{2}$ in PDGF-stimulated cultures exceeded the quiescent control cells by a factor of $10-$ 15. Quiescent cells incubated with up to $16 \mu \mathrm{M}$ exogenous arachidonic acid (AA) synthesized only small amounts of $\mathrm{PGE}_{2}$. In contrast, $4 \mathrm{~h}$ after addition of PDGF, the concentration of $\mathrm{PGE}_{2}$ synthesized from exogenous $\mathrm{AA}$ exceeded that in quiescent cultures by a factor of 28 . The effect of PDGF stimulation on PG synthesis from exogenous AA could not be explained by growth factor-mediated increase in the cellular free AA pool as shown in experiments using $\left[{ }^{14} \mathrm{C}\right] \mathrm{AA}$. PDGF also stimulated synthesis of $\mathrm{PGI}_{2}$ (prostacyclin), thromboxane, and $\mathrm{PGF}_{2 \alpha}$ from exogenous $\mathrm{AA}$. While inhibition of protein synthesis by $10 \mu \mathrm{g} / \mathrm{ml}$ cycloheximide had no effect on the early increase in $\mathrm{PGE}_{2}$ synthesis, the second increase was completely prevented. Additionally, cycloheximide treatment at $6 \mathrm{~h}$ after PDGF stimulation resulted in rapid decline of $\mathrm{PGE}_{2}$ synthesis from exogenous AA. Quiescent cultures pretreated with $100 \mu \mathrm{M}$ aspirin and stimulated by PDGF thereafter recovered from cyclooxygenase inhibition within $180 \mathrm{~min}$. Our results suggest that phospholipase activation and resultant $\mathbf{A A}$ release is not sufficient to induce the burst of PG synthesis observed in PDGF-stimulated cells. Instead, PDGF stimulates PG synthesis by direct effects on the PG-synthesizing enzyme system, one involving a protein synthesis-independent mechanism and another that requires rapid translation of cyclooxygenase.
\end{abstract}

\section{Introduction}

The relation between phospholipase activation resulting in liberation of arachidonic acid (AA) ${ }^{1}$ from complex glycerolipids and the cyclooxygenase pathway generating prostaglandins

This work was presented in part at the International Congress of Inflammation, Paris, 3-7 September 1984.

Address reprint requests to Dr. Habenicht, University of Heidelberg, Bergheimer Str. 58, 6900 Heidelberg, Federal Republic of Germany.

Received for publication 18 September 1984 and in revised form 18 December 1984.

1. Abbreviations used in this paper: AA, arachidonic acid; PDS, plasmaderived serum; PG, prostaglandin; PDGF, platelet-derived growth factor; TX, thromboxane.

J. Clin. Invest.

(C) The American Society for Clinical Investigation, Inc. 0021-9738/85/04/1381/07 \$1.00

Volume 75, April 1985, 1381-1387
(PGs) and thromboxanes (TXs) is not entirely clear. Upon binding of hormones or other agonists to their respective cell surface receptor, AA is released from phospholipids through activation of phospholipases (1-9). In most if not all such instances, activation of phospholipases is associated with production of PGs and TXs $(1,2,5,9,10)$. Therefore, it is generally believed that phospholipases control formation of PGs through release of AA. Since the intracellular pool of AA is low in mammalian cells $(3,6)$, there is little doubt that eicosanoid biosynthesis is dependent on phospholipase activity. However, it is less clear whether liberation of AA is sufficient to induce the burst of PG, TX, and leukotriene formation observed in many agonist response systems.

We have used quiescent Swiss 3T3 cells stimulated to divide by platelet-derived growth factor (PDGF), the principal mitogen for connective tissue-derived cells (11-13), as model systems to study the relation between growth factor-induced changes in phospholipid metabolism and AA release (14-16). Cells maintained in plasma-derived serum (PDS) become arrested in the $G_{0} / G_{1}$ phase of the cell cycle and can be stimulated to undergo cell cycle traverse after stimulation by PDGF in a partially synchronized fashion (17). We proposed that PDGF and epidermal growth factor stimulate AA release from phosphatidylinositol, a minor acidic phospholipid in mammalian cells, by activation of the phospholipase $\mathrm{C} /$ diglyceride lipase pathway $(14,15)$. This reaction sequence was first described by Bell et al. (18) and Majerus et al. (19) in thrombin-stimulated platelets.

The question we have addressed in the present report has been whether PDGF has direct effects on the PG synthesis pathway. It was of special interest to us whether PDGF has direct stimulatory effects on the key enzyme, the cyclooxygenase. Our results show that AA release from glycerolipids is not sufficient to induce the burst in PG synthesis in PDGFstimulated cells $(15,20,21)$. Instead, the growth factor greatly activates the PG synthetic enzyme system itself. This effect of PDGF appears to be mediated by both activation and rapid de novo synthesis of the cyclooxygenase.

\section{Methods}

Materials. $\left[1{ }^{14} \mathrm{C}\right] \mathrm{AA}$ (sp act, $\left.56.9 \mathrm{mCi} / \mathrm{mmol}\right),\left[{ }^{3} \mathrm{H}\right] 6-\mathrm{keto}-\mathrm{PGF}_{1 \alpha}$ (sp act, $120 \mathrm{Ci} / \mathrm{mmol}$ ), $\left[{ }^{3} \mathrm{H}\right] \mathrm{PGF}_{2 \alpha}$ (sp act, $150 \mathrm{Ci} / \mathrm{mmol}$ ), $\left[{ }^{3} \mathrm{H}\right] \mathrm{PGE}_{2}$ (sp act, $160 \mathrm{Ci} / \mathrm{mmol}$ ), $\left[{ }^{3} \mathrm{H}\right] \mathrm{TXB}_{2}$ (sp act, $139 \mathrm{Ci} / \mathrm{mmol}$ ) was obtained from New England Nuclear, Boston, MA; Dulbecco's modification of Eagle's medium from Gibco Laboratories, Grand Island, NY; methanol, ethanol, ethylacetate, benzene, acetone, dioxane, acetic acid, 200- $\mu \mathrm{m}$ silica gel-coated aluminum thin-layer chromatograms from Merck Inc., Darmstadt, Federal Republic of Germany; standard PGs were purchased from Seragen, Boston, MA; antibodies against $\mathrm{PGE}_{2}, 6-\mathrm{keto}^{-} \mathrm{PGF}_{1 \alpha}$, $\mathrm{TXB}_{2}$, and $\mathrm{PGF}_{2 \alpha}$ from the Institute Pasteur, Paris; cycloheximide from Sigma Chemie, Munich, Federal Republic of Germany; AA from P. L. Biochemicals, St. Goar, Federal Republic of Germany. 
Plasma proteins and PDGF. Human or calf PDS lacking plateletderived growth promoting activity was prepared as described (17). PDGF was prepared as described by Raines and Ross (22). PDGF at $12 \mathrm{ng} / \mathrm{ml}$ maximally stimulated DNA synthesis in Swiss 3T3 cells.

Radioimmunoassay (RIA). The concentration of PGs was determined by RIA according to Granstrom and Kindahl (23) after reversedphase extraction of the culture medium by octadecyl $\mathrm{C} 18$ silica gel column chromatography according to Powell (24) and thin-layer chromatography. Briefly, $1 \mathrm{ml}$ culture medium was removed from the dish and acidified to $\mathrm{pH}$ 3.6. $900 \mu \mathrm{l}$ of the culture medium was applied to an octadecyl $\mathrm{C} 18$ silica gel column equilibrated with methanol. The column was washed twice with $3 \mathrm{ml}$ double distilled $\mathrm{H}_{2} \mathrm{O}$, and the PGs were eluted with a total volume of $1.5 \mathrm{ml}$ ethylacetate. The ethylacetate was dried down under a stream of $\mathrm{N}_{2}$, taken up in $1 \mathrm{ml}$ methanol, and stored until further analysis at $-26^{\circ} \mathrm{C}$. Before thinlayer chromatography, the methanol was dried down and the extract taken up in $150 \mu \mathrm{l}$ ethanol, applied to a $200 \mu \mathrm{m}$ silica gel-coated aluminum thin-layer chromatogram, and developed in solvent system of benzene/acetone/methanol/dioxane/ $\mathrm{H}_{2} \mathrm{O}, 120: 80: 6: 3: 2 ; \mathrm{vol} / \mathrm{vol}$. The spot containing the respective PG was scraped from the plate and extracted with $2 \mathrm{ml}$ in methanol, dried down under a stream of $\mathrm{N}_{2}$, and taken up in phosphate-buffered saline. Procedural losses were monitored by adding tracer $\left[{ }^{3} \mathrm{H}\right] \mathrm{PGs}$ to each sample. Recoveries of $\mathrm{PGE}_{2}$ ranged from $34-61 \%$, for 6-keto-PGF ${ }_{1 \alpha}$ from $54-68 \%$, and for $\mathrm{TXB}_{2}$ from $48-72 \%$. Cross-reactivity at $50 \%$ binding of $\mathrm{PGE}_{2}$ was $10.1 \%$ with $\mathrm{PGE}_{1} ;<0.2 \%$ with $\mathrm{PGA}_{1}, \mathrm{PGA}_{2}, \mathrm{PGB}_{1}, \mathrm{PGB}_{2}, \mathrm{PGD}_{2}$,

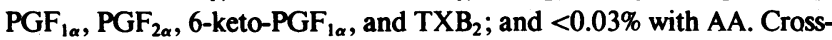
reactivity at $50 \%$ binding of $6-$ keto- $^{-} \mathrm{PGF}_{1 \alpha}$ was $6.8 \%$ with $6-\mathrm{keto}^{-} \mathrm{PGE}_{1}$, $2.2 \%$ with $\mathrm{PGF}_{2 \alpha}, 0.7 \%$ with $\mathrm{PGE}_{1}, 0.5 \%$ with $\mathrm{PGE}_{2},<0.1 \%$ with all other PGs tested, and $<0.3 \%$ with $\mathrm{AA}$. Water samples subjected to exactly the same treatment as the biological samples ranged between 0 and $7 \mathrm{pg} / \mathrm{ml}$ for $\mathrm{PGE}_{2}$ and $<5-15 \mathrm{pg} / \mathrm{ml}$ for 6-keto-PGF $\mathrm{PG}_{1 \alpha}$. Intraassay variation for $\mathrm{PGE}_{2}$ was 2-9\% and for 6-keto- $\mathrm{PGF}_{1 \alpha}$ was $7-11 \%$. Interassay variation for $\mathrm{PGE}_{2}$ was $5-12 \%$ and for $6-\mathrm{keto}^{-\mathrm{PGF}_{1 \alpha} \text { was }}$ $8-22 \%$.

\section{Results}

Kinetics of $P G E_{2}$ synthesis in the cell cycle of Swiss $3 T 3$ cells stimulated by $P D G F$. The synthesis kinetics of $\mathrm{PGE}_{2}$ in quiescent and PDGF-stimulated cells is shown in Fig. 1, $A$ and $B$. We consistently observed in five experiments an early burst of $\mathrm{PGE}_{2}$ formation that was complete within $10 \mathrm{~min}$. At 2 min, PDGF caused a statistically significant increase in $\mathrm{PGE}_{2}$ formation (Fig. $1 \mathrm{~B}$ ). No further increase was observed until 2-4 $\mathrm{h}$ (Figs. 1 and 3). At that time, another sharp rise in $\mathrm{PGE}_{2}$ levels was observed. No additional increase was detected for the next $18 \mathrm{~h}$. Thus, PDGF stimulated $\mathrm{PGE}_{2}$ synthesis in the cell cycle during two distinct time intervals: a first early increase that was complete within $10 \mathrm{~min}$, and a second increase between 2 and $4 \mathrm{~h}$.

$P D G F$ stimulates $P G E_{2}$ synthesis from exogenous $A A$. To test the ability of the cells to metabolize exogenous AA to $\mathrm{PGE}_{2}$, we incubated quiescent and PDGF-stimulated cells with increasing concentrations of AA (Fig. 2). Though the quiescent cultures were receiving concentrations of $\mathrm{AA}$ as high as $16 \mu \mathrm{M}$, they synthesized only small amounts of $\mathrm{PGE}_{2}$. In contrast, cells stimulated by PDGF synthesized up to $100 \mathrm{ng}$ $\mathrm{PGE}_{2} / 10^{6}$ cells in the first $60 \mathrm{~min}$ of the cell cycle in all of five experiments. Concentrations between 4 and $16 \mu \mathrm{M}$ AA did not further increase $\mathrm{PGE}_{2}$ synthesis both in quiescent and PDGF-stimulated cells. Therefore, a concentration of $10 \mu \mathrm{M}$ AA was chosen for all future experiments. The ability of PDGF to stimulate $\mathrm{PGE}_{2}$ biosynthesis from exogenous $\mathrm{AA}$ might have been due to a PDGF-mediated increase in the
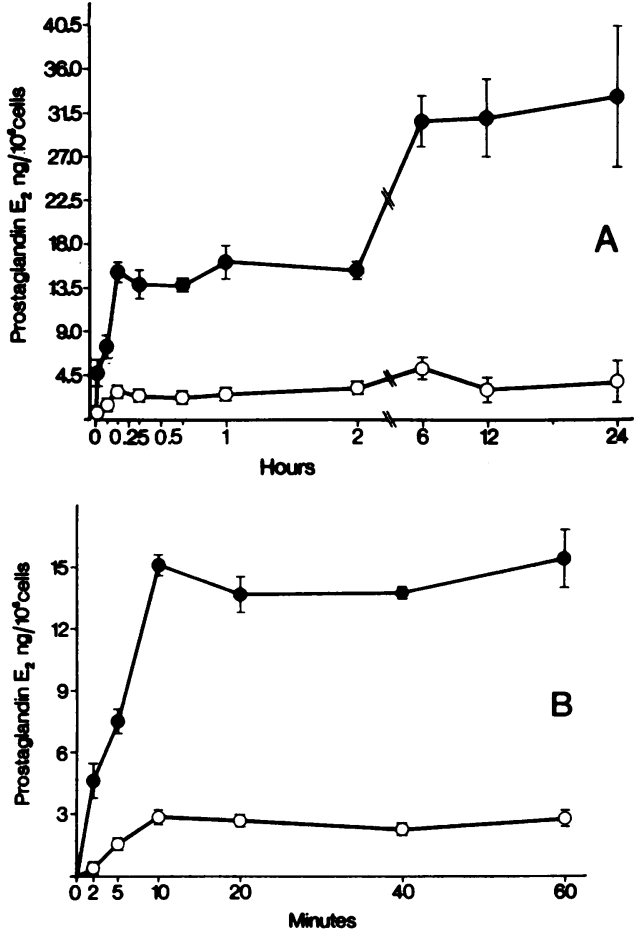

Figure 1. Kinetics of $\mathrm{PGE}_{2}$ synthesis in the cell cycle of Swiss 3T3 cells stimulated by PDGF. Swiss 3 T3 cells were plated at a density of $1.25 \times 10^{5}$ cells in 35-mm Costar plates (Costar, Cambridge, MA) containing $1.5 \mathrm{ml}$ of Dulbecco's modification of Eagle's medium (Gibco Laboratories) supplemented with $100 \mathrm{U} /$ liter penicillin, 100 $\mu \mathrm{g} / \mathrm{ml}$ streptomycin, and $1.25 \mathrm{mg} / \mathrm{ml}$ PDS protein. On day 3 , the cultures were fed with the same medium and divided into two groups, and received either $50 \mu 110 \mathrm{mM}$ acetic acid (o) or $12 \mathrm{ng} / \mathrm{ml}$ PDGF in a concentrated solution of $50 \mu 110 \mathrm{mM}$ acetic acid (๑). 12 $\mathrm{ng} / \mathrm{ml}$ PDGF stimulated $1.25 \times 10^{5}$ cells to double within $36 \mathrm{~h}$. The same amount of PDGF stimulated incorporation of [methyl-

${ }^{3} \mathrm{H}$ ]thymidine into trichloroacetic acid-precipitable material by a factor of 12-35 when assayed between 23 and $24 \mathrm{~h}$. At the time points indicated in the figure ( $A$, hours; $B$, minutes), $1 \mathrm{ml}$ culture medium was removed from the dish and acidified to $\mathrm{pH}$ 3.6. The concentration of $\mathrm{PGE}_{2}$ was determined by RIA as described under Methods. Treatment of the cultures using $100 \mu \mathrm{M}$ aspirin completely prevented formation of $\mathrm{PGE}_{2}$. The points indicated represent the means of three parallel cultures \pm SD.

cellular free AA pool, thus making more AA available to the cyclooxygenase. Therefore, we determined the effects of PDGF on this pool after various times of stimulation with the growth factor (Table I). PDGF had only minor effects on free $\left[{ }^{14} \mathrm{C}\right] \mathrm{AA}$. Analysis of individual phospholipids by two-dimensional thinlayer chromatography indicated that PDGF stimulated $\left[{ }^{14} \mathrm{C}\right] \mathrm{AA}$ incorporation into phosphatidic acid, phosphatidylinositol, and triacylglycerol (16).

We next determined the cell cycle kinetics of $\mathrm{PGE}_{2}$ synthesis from exogenous AA. As shown in Fig. 3, the second rise in endogenous $\mathrm{PGE}_{2}$ synthesis which occurred between 2 and 4 $\mathrm{h}$ was associated with a second sharp increase in the formation of $\mathrm{PGE}_{2}$ from exogenous $\mathrm{AA}$. The concentration of $\mathrm{PGE}_{2}$ in PDGF-stimulated cultures incubated with $10 \mu \mathrm{M}$ AA for 60 min rose from 60 to $100 \mathrm{ng} / 10^{6}$ cells in the first $2 \mathrm{~h}$ up to 280 $\mathrm{ng} / 10^{6}$ cells at $4 \mathrm{~h}$ in all of four experiments. Cells that had been stimulated by PDGF at time 0 and were incubated with $10 \mu \mathrm{M}$ AA from 5 to $6 \mathrm{~h}$ synthesized up to 90 times more 


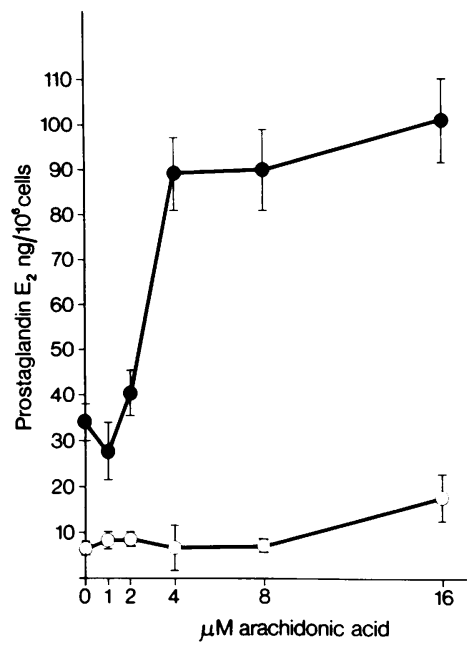

Figure 2. Synthesis of $\mathrm{PGE}_{2}$ from exogenous AA in quiescent and PDGFstimulated Swiss $3 \mathrm{~T} 3$ cells. Swiss 3T3 cells were cultured as described in Fig. 1. On day 3, the cultures were fed with medium containing $1.25 \mathrm{mg} / \mathrm{ml}$ PDS protein and divided into two groups; one group received $12 \mathrm{ng} / \mathrm{ml}$ PDGF in a concentrated solution of $50 \mu \mathrm{l}$ $10 \mathrm{mM}$ acetic acid and increasing concentrations of AA dissolved in $10 \mu \mathrm{l}$ ethanol (•), to give a final concentration of AA as indicated. Control cultures received $50 \mu 10 \mathrm{mM}$

acetic acid and increasing concentrations of AA (O). Cultures that were not incubated with AA received $10 \mu$ l ethanol instead. AA was obtained from P. L. Biochemicals (St. Goar, Federal Republic of Germany), and multiple aliquots of a $10-\mathrm{mM}$ stock solution were stored in ethanol under argon at $-85^{\circ} \mathrm{C}$. After $60 \mathrm{~min}$, upon addition of PDGF and AA/ethanol, $\mathrm{PGE}_{2}$ levels were determined as described under Methods. The data points represent the means of three parallel cultures \pm SD.

$\mathrm{PGE}_{2}$ when compared with quiescent cells and up to 28 times when compared with quiescent cells incubated with 10 $\mu \mathrm{M}$ AA.

$P D G F$ stimulates prostacyclin and $T X B_{2}$ synthesis from exogenous $A A$. Since PDGF greatly stimulated $\mathrm{PGE}_{2}$ synthesis from exogenous AA without comparable stimulation of the intracellular $\left[{ }^{14}\right] \mathrm{AA}$ pool, it seemed that the growth factor had direct stimulatory effects on one or more enzymes involved in PG synthesis. To test this hypothesis further, we determined the levels of 6-keto-PGF P $_{1 \alpha}$ (the stable hydrolysis product of prostacyclin), another major cyclooxygenase-derived product

Table I. Effect of PDGF on Radioactivity of the Cellular Free Fatty Acid Pool Using $\left[1-{ }^{14} \mathrm{C}\right] \mathrm{AA}$

\begin{tabular}{llll}
\hline Additions & $1 \mathrm{~h}$ & $2 \mathrm{~h}$ & $16 \mathrm{~h}$ \\
\hline & $d p m \times 10^{3} / d i s h$ & $d p m \times 10^{3} / d i s h$ & $d p m \times 10^{3} / d i s h$ \\
Control & $4.8 \pm 0.6$ & $6.6 \pm 2.2$ & $10.2 \pm 1.2$ \\
+PDGF & $5.8 \pm 0.6$ & $10.4 \pm 0.8$ & $11.6 \pm 0.6$
\end{tabular}

Swiss $3 T 3$ cells were cultured as described in Fig. 1. On day 3, the cultures were divided into two groups and either received $50 \mu 10$ $\mathrm{mM}$ acetic acid (control) or $4 \mu \mathrm{g} / \mathrm{ml}$ partially purified PDGF dissolved in a concentrated solution of $50 \mu 110 \mathrm{mM}$ acetic acid. The amount of PDGF present in this preparation is equivalent to the amounts of highly purified PDGF used in the experiments in Figs. 13 and 5-7. At time 0 , the cultures were incubated with $11.7 \mu \mathrm{M}$ $\left[1-{ }^{14} \mathrm{C}\right] \mathrm{AA}$ dissolved in $10 \mu \mathrm{l}$ ethanol. At the time points indicated, the culture medium was removed and the cell monolayer washed three times with ice-cold phosphate-buffered saline. Free fatty acids were extracted and separated by thin-layer chromatography as described (14). The silica gel was transferred to a scintillation vial and radioactivity was determined in a PW 4700 Philips Scintillation Spectrometer (Philips, Eindhoven, The Netherlands). The numbers represent the means of three parallel cultures $\pm S D$.

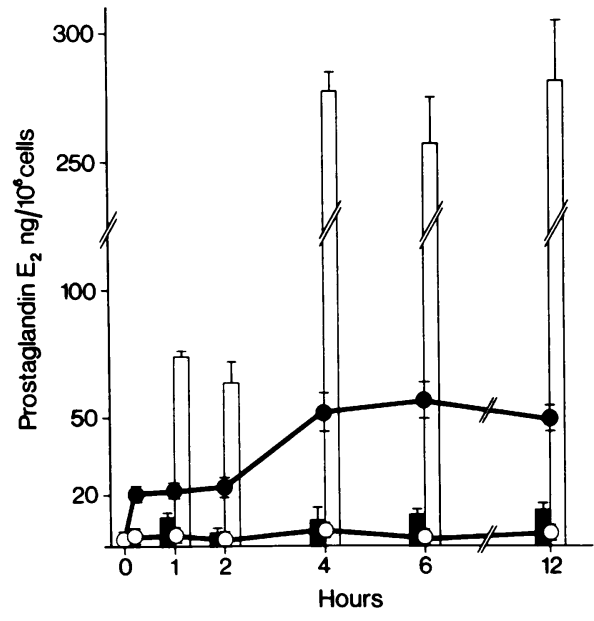

Figure 3. Kinetics of $\mathrm{PGE}_{2}$ synthesis from exogenous $\mathrm{AA}$ in quiescent and PDGF-stimulated Swiss 3T3 cells. Swiss 3T3 cells were cultured as described in Fig. 1. On day 3, the cultures were fed with medium containing $1.25 \mathrm{mg} / \mathrm{ml}$ PDS protein, divided into two groups, and received either $50 \mu 110 \mathrm{mM}$ acetic acid (O) or $12 \mathrm{ng} / \mathrm{ml}$ PDGF in a concentrated solution of $50 \mu 110 \mathrm{mM}$ acetic acid (•). Closed bars represent cultures that received $50 \mu 10 \mathrm{mM}$ acetic acid at time 0 and $10 \mu \mathrm{M}$ AA dissolved in a concentrated solution of 10 $\mu \mathrm{l}$ ethanol $60 \mathrm{~min}$ before each time point indicated. Open bars represent cultures that received $12 \mathrm{ng} / \mathrm{ml}$ PDGF in a concentrated solution of $50 \mu 110 \mathrm{mM}$ acetic acid at time 0 and $10 \mu \mathrm{M} \mathrm{AA}$ dissolved in a concentrated solution of $10 \mu$ l ethanol $60 \mathrm{~min}$ before the bars indicated in the figure. $\mathrm{PGE}_{2}$ levels were determined as described under Methods. Cultures that did not receive AA were incubated with $10 \mu l$ ethanol instead. The data represent the means of three parallel cultures \pm SD.

of AA in Swiss 3 T3 cells (25), over a period of $12 \mathrm{~h}$ (Fig. 4). 6-keto-PGF - $_{1 \alpha}$ levels increased up to $2 \mathrm{~h}$ upon stimulation by PDGF and then remained relatively constant or increased slightly for the next $10 \mathrm{~h}$. In addition, PDGF-stimulated 6keto-PGF ${ }_{1 \alpha}$ formation from exogenous AA (Fig. 4). When PDGF stimulated cells incubated with AA were compared with quiescent cells incubated with $\mathrm{AA}$, it became apparent that the growth factor stimulated 6-keto-PGF ${ }_{1 \alpha}$ synthesis by a factor of 27-35 in two experiments. Thus, the degree of stimulation of 6-keto-PGF $\mathrm{PG}_{1 \alpha}$ formation from exogenous $\mathrm{AA}$ was similar to that of $\mathrm{PGE}_{2}$ synthesis (Fig. 3). Other experiments demonstrated comparable effects of PDGF on synthesis of $\mathrm{TXB}_{2}$ and $\mathrm{PGF}_{2 \alpha}$ from exogenous AA (results not shown).

$P D G F$ stimulates $P G$ synthesis by two distinct mechanisms. To obtain further information on the mechanism of PG synthesis stimulation by the growth factor, we examined the effect of the protein synthesis inhibitor cycloheximide on synthesis of $\mathrm{PGE}_{2}$ (Table II). The concentration of cycloheximide used inhibited protein synthesis $>90 \%$ as determined by $\left[{ }^{14} \mathrm{C}\right]$ leucine incorporation into trichloroacetic acid-precipitable material. While cycloheximide did not inhibit the early increase of endogenous $\mathrm{PGE}_{2}$ synthesis, the second increase was completely prevented. Since this effect of cycloheximide might have been due to protein synthesis-sensitive phospholipase activation and $A A$ release, we determined $\mathrm{PGE}_{2}$ synthesis after cycloheximide treatment from exogenous AA (Table II). Cycloheximide did not alter the early increase of $\mathrm{PGE}_{2}$ synthesis from exogenous AA while it completely prevented the second increase. In other experiments, PDGF-stimulated cells were 


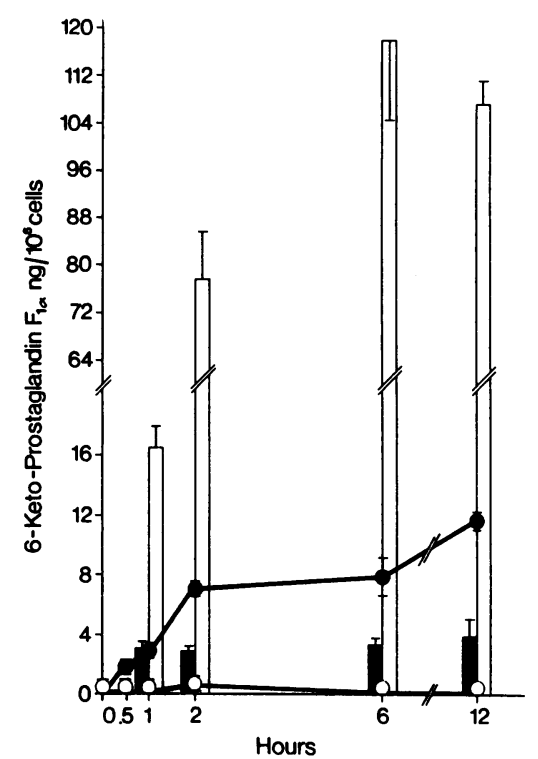

Figure 4. Kinetics of $\mathrm{PGI}_{2}$ synthesis in the cell cycle of Swiss 3T3 cells stimulated by PDGF. Swiss 3T3 cells were cultured as described in Fig. 1. On day 3, the cultures were fed with medium containing $1.25 \mathrm{mg} / \mathrm{ml}$ PDS protein, divided into two groups, and received either $50 \mu 110 \mathrm{mM}$ acetic acid (o) or $4 \mu \mathrm{g} / \mathrm{ml}$ partially purified PDGF dissolved in $50 \mu 110 \mathrm{mM}$ acetic acid (๑). This amount of partially purified PDGF is equivalent in PDGF content to the amounts of highly purified PDGF used in the experiments detailed in Figs. 1-3 and 5-7. Closed bars represent cultures that received $50 \mu 1$ $10 \mathrm{mM}$ acetic acid at time 0 and, $60 \mathrm{~min}$ before the bars, $10 \mu \mathrm{M}$ AA dissolved in $10 \mu \mathrm{l}$ ethanol. Cultures that did not receive AA were incubated with $10 \mu \mathrm{l}$ ethanol instead. PGI $_{2}$ levels were determined by RIA of 6-keto-PGF ${ }_{1 \alpha}$, the stable degradation product of $\mathbf{P G I}_{2}$ as described under Methods. Culture medium was treated as described for $\mathrm{PGE}_{2}$. However, before thin-layer chromatography, PG extracts from two cultures were pooled to obtain sufficient amounts of 6keto-PGF $1 \alpha$ for determination by RIA. The data represent the means of three parallel pooled duplicate cultures \pm SD.

incubated with cycloheximide at $6 \mathrm{~h}$. A rapid decline in $\mathrm{PGE}_{2}$ synthesis from exogenous AA was observed (Fig. 5). These results showed that the growth factor stimulated the PG synthetic enzyme system by two independent mechanisms: one that was insensitive to protein synthesis inhibition and another requiring translational activity. It is noteworthy that

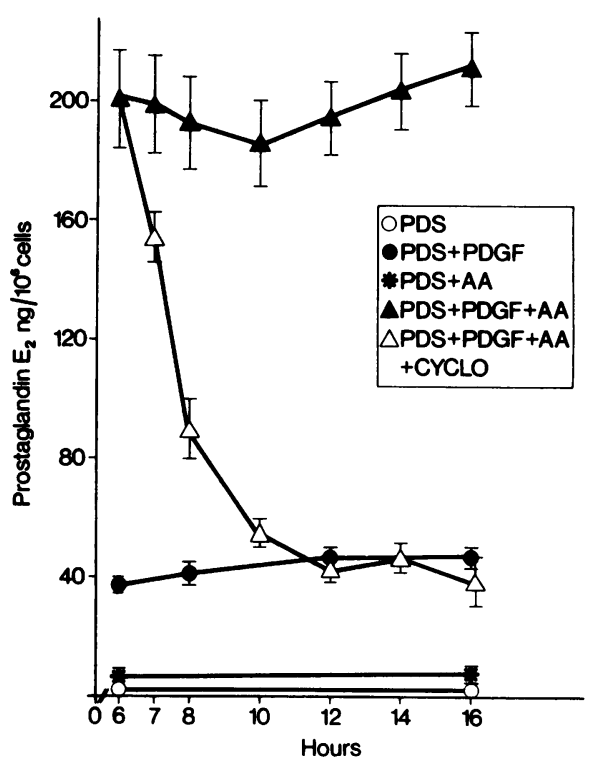

Figure 5. Kinetics of $\mathrm{PGE}_{2}$ synthesis from exogenous AA in PDGFstimulated Swiss 3T3 cells incubated with cycloheximide. Swiss 3T3 cells were cultured as described in Fig. 1. On day 4, the cultures were fed with medium containing $1.25 \mathrm{mg} / \mathrm{ml}$ PDS protein, divided into two groups, and received either $50 \mu 110 \mathrm{mM}$ acetic acid or $12 \mathrm{ng} / \mathrm{ml}$ PDGF in a concentrated solution of $50 \mu 110 \mathrm{mM}$ acetic acid. 60 min before the time points indicated, parallel cultures were incubated with $10 \mu \mathrm{l}$ ethanol or $10 \mu \mathrm{M}$ AA dissolved in a concentrated solution of $10 \mu$ lethanol. $6 \mathrm{~h}$ after stimulation with PDGF, parallel cultures received $10 \mu \mathrm{g} / \mathrm{ml}$ cycloheximide. $\mathrm{PGE}_{2}$ was determined as described under Methods. The data represent the means of three parallel cultures \pm SD.

cycloheximide did not compromise the viability of the cells as judged by trypan exclusion under our experimental conditions.

$P D G F$ stimulates activation and rapid de novo synthesis of cyclooxygenase. To determine whether PDGF had direct effects on cyclooxygenase, we preincubated quiescent cells with aspirin (26). We then determined the kinetics of recovery by measurement of $\mathrm{PGE}_{2}$ synthesis from exogenous AA upon removal of aspirin and stimulation with PDGF (Fig. 6). The stimulated cells largely recovered between 2 and $4 \mathrm{~h}$. Furthermore, aspirin treatment resulted in up to $45 \%$ enhanced $\mathrm{PGE}_{2}$ synthesis from exogenous AA when compared with PDGF-stimulated

Table II. Effects of Cycloheximide on PGE, Synthesis from Endogenous and Exogenous AA in Quiescent and PDGF-stimulated Swiss $3 T 3$ Cells

\begin{tabular}{|c|c|c|c|c|c|c|c|c|}
\hline $\begin{array}{l}\text { Hours after } \\
\text { addition of } \\
\text { PDGF }\end{array}$ & PDS & $\begin{array}{l}\text { PDS plus } \\
\text { PDGF }\end{array}$ & $\begin{array}{l}\text { PDS plus cy- } \\
\text { cloheximide }\end{array}$ & $\begin{array}{l}\text { PDS plus } \\
\text { PDGF plus } \\
\text { cycloheximide }\end{array}$ & $\begin{array}{l}\text { PDS plus } \\
\text { AA }\end{array}$ & $\begin{array}{l}\text { PDS plus } \\
\text { PDGF plus } \\
\text { AA }\end{array}$ & $\begin{array}{l}\text { PDS plus AA } \\
\text { plus cyclo- } \\
\text { heximide }\end{array}$ & $\begin{array}{l}\text { PDS plus AA } \\
\text { PDGF plus } \\
\text { cycloheximide }\end{array}$ \\
\hline & \multicolumn{8}{|c|}{ Prostaglandin $E_{2} \mathrm{ng} / 10^{6}$ cells } \\
\hline 1 & $2.1 \pm 0.3$ & $24.0 \pm 3.5$ & $2.8 \pm 0.1$ & $22.0 \pm 1.1$ & $7.9 \pm 1.5$ & $109.0 \pm 5.9$ & $6.4 \pm 0.8$ & $104.2 \pm 6.9$ \\
\hline 3 & $3.8 \pm 0.3$ & $47.2 \pm 1.4$ & $3.6 \pm 1.7$ & $26.4 \pm 3.2$ & $7.2 \pm 0.8$ & $216.0 \pm 17.3$ & $6.2 \pm 2.8$ & $102.4 \pm 20.8$ \\
\hline
\end{tabular}

Swiss 3T3 cells were cultured as described in Fig. 1. On day 4, the cultures were fed with medium containing $1.25 \mathrm{mg} / \mathrm{ml}$ PDS protein, divided into two groups, and received either $50 \mu 10 \mathrm{mM}$ acetic acid or $12 \mathrm{ng} / \mathrm{ml}$ PDGF dissolved in a concentrated solution of $50 \mu \mathrm{l} 10 \mathrm{mM}$ acetic acid. $90 \mathrm{~min}$ before the time points indicated in the table, parallel cultures were incubated with $10 \mu \mathrm{g} / \mathrm{ml} \mathrm{cycloheximide} \mathrm{dissolved} \mathrm{in} 50 \mu \mathrm{l}$ phosphate-buffered saline. $60 \mathrm{~min}$ before the time points indicated, parallel cultures were incubated with $10 \mu \mathrm{M}$ AA dissolved in $10 \mu \mathrm{l}$ ethanol. Control cultures received $10 \mu \mathrm{l}$ ethanol instead. PGE 2 levels were determined as described in Fig. 1. The data represent the means of three parallel cultures \pm 1 SD. 


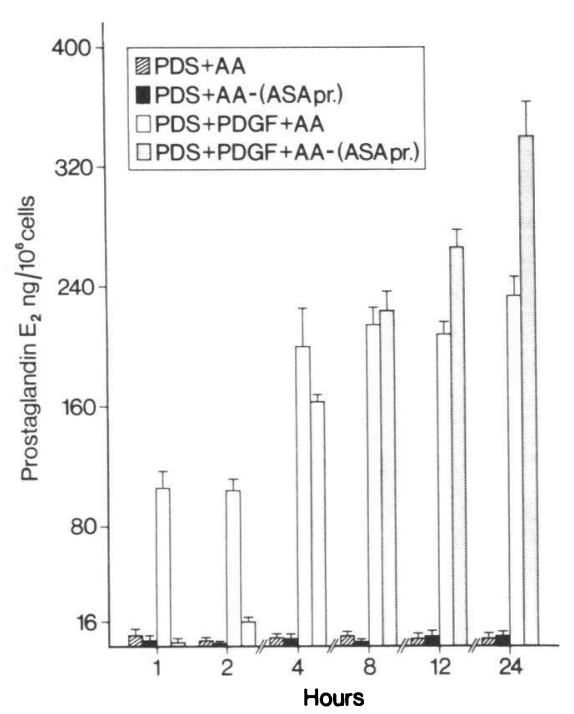

Figure 6. Recovery of $\mathrm{PGE}_{2}$ synthesis from exogenous $\mathrm{AA}$ after inhibition of cyclooxygenase by aspirin in quiescent Swiss 3T3 cells stimulated by PDGF. Swiss 3T3 cells were cultured as described in Fig. 1. On day 4, the cultures were fed with medium containing 1.25 $\mathrm{mg} / \mathrm{ml}$ PDS protein. 30 min before the medium was changed, parallel cultures were incubated with $50 \mu \mathrm{l}$ phosphate-buffered saline or $100 \mu \mathrm{M}$ aspirin (ASA pr.) dissolved in $50 \mu \mathrm{l}$ phosphate-buffered saline. Before replacement of the medium containing PDS protein, the monolayers were washed twice with $2 \mathrm{ml}$ phosphate-buffered saline to remove residual aspirin. At the time of the medium change the cultures were divided into two groups and received either $50 \mu \mathrm{l}$ $10 \mathrm{mM}$ acetic acid or $12 \mathrm{ng} / \mathrm{ml}$ PDGF in a concentrated solution of $50 \mu 110 \mathrm{mM}$ acetic acid. $60 \mathrm{~min}$ before each time point indicated in the figure, the cultures were incubated with $10 \mu \mathrm{M}$ AA dissolved in a concentrated solution of $10 \mu \mathrm{l}$ ethanol. $\mathrm{PGE}_{2}$ levels were determined as described under Methods. The data represent the means of three parallel cultures \pm SD.

cells in three experiments. No significant recovery from aspirin treatment was observed within the first $2 \mathrm{~h}$ after PDGF stimulation.

We next examined the kinetics of recovery from cyclooxygenase inhibition in PDGF-treated cells (Fig. 7). Complete recovery was observed within $180 \mathrm{~min}$ in PDGF-stimulated cells when cyclooxygenase inhibition was initiated between 5.5 and $7 \mathrm{~h}$. The kinetics of recovery from cyclooxygenase inhibition (Fig. 7) was similar to the kinetics of inhibition of $\mathrm{PGE}_{2}$ synthesis from exogenous AA after protein synthesis inhibition (Fig. 5). In addition, recovery from cyclooxygenase inhibition by aspirin was completely prevented by cycloheximide (results not shown).

\section{Discussion}

The experiments performed in this investigation focused on the possibility that human PDGF stimulated synthesis of PGs by direct activation of the cyclooxygenase pathway.

The generally accepted view of PG synthesis regulation has been that AA hydrolysis from complex glycerolipids represents the major control mechanism of PG biosynthesis (1-3, 6, 9, 18). However, this concept is based on circumstantial evidence; the intracellular pool of free AA, the substrate for the cyclooxygenase, is low in mammalian cells $(2,3,5,6,18)$ and inhibitors of phospholipase activity have been shown to suppress

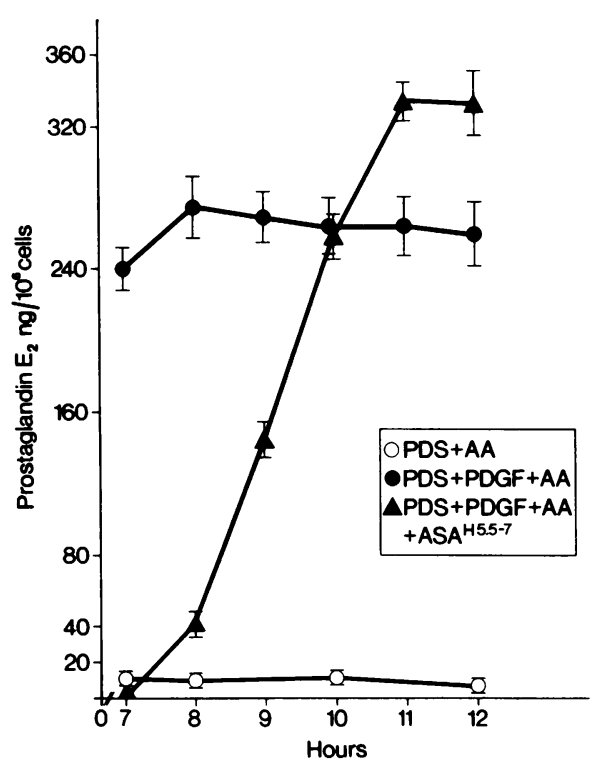

Figure 7. Kinetics of recovery from cyclooxygenase inhibition by aspirin $7 \mathrm{~h}$ after stimulation of quiescent Swiss 3T3 cells with PDGF. Swiss $3 \mathrm{~T} 3$ cells were cultured as described in Fig. 1 . On day 4 , the cultures were fed with medium containing $1.25 \mathrm{mg} / \mathrm{ml}$ PDS protein, divided into two groups, and received either $50 \mu 10 \mathrm{mM}$ acetic acid or $12 \mathrm{ng} / \mathrm{ml}$ PDGF in a concentrated solution of $50 \mu 110 \mathrm{mM}$ acetic acid. Before the time points indicated, the cultures received $10 \mathrm{mM}$ AA dissolved in a concentrated solution of ethanol. Between 5.5 and $7 \mathrm{~h}$, parallel cultures were incubated with $50 \mu \mathrm{l}$ phosphate-buffered saline or $100 \mu \mathrm{M}$ aspirin (ASA h 5.5-7) dissolved in $50 \mu$ l phosphatebuffered saline. Before addition of aspirin, the medium of the cultures was replaced by fresh medium containing $1.24 \mathrm{mg} / \mathrm{ml}$ PDS protein to remove PGs that had accumulated during the $5.5 \mathrm{~h}$ after PDGF stimulation. $\mathrm{PGE}_{2}$ levels were determined as described under Methods. The data represent the means of three parallel cultures \pm SD.

PG synthesis from endogenous but not exogenous AA (27). Furthermore most if not all agonists eliciting increased PG synthesis concomitantly induce release of AA from phospholipids $(3,9,14,15,20,21,28-30)$. While these studies are consistent with a critical role of phospholipase activity for PG synthesis, they do not provide information on several important questions: First, is AA release induced by phospholipases sufficient to induce the burst of PG synthesis observed in many agonist response systems? Second, what are the determining factors of regulation of the PG synthetic enzymes, and particularly, the cyclooxygenase? Work on mechanisms of regulation of the cyclooxygenase on the other hand has been difficult because this enzyme is subject to rapid inactivation by endoperoxide intermediates in cultured cells (31).

Several lines of published evidence suggest, however, that PG synthesis regulation is not simply the result of increased phospholipase activity. Thus, Bonser et al. (32) obtained evidence in cultured Swiss 3T3 cells that both bradykinin and thrombin stimulate PG synthesis from exogenous AA and Hyman et al. (25) showed that quiescent Swiss 3T3 cells form less PGs from exogenous AA when compared with their rapidly proliferating counterparts maintained in high serum concentrations. Furthermore, Ogekawa et al. (33) demonstrated that both the perfused hydronephrotic kidney and microsomes prepared from the renal cortex of ureter-obstructed kidneys 
show greatly enhanced $\mathrm{PGE}_{2}$ synthesis from exogenous AA. Enhanced $\mathrm{PGE}_{2}$ synthesis from exogenous $\mathrm{AA}$ appears to correlate best with the proliferation of fibroblast-like cells in this system. These results are consistent with the possibility that PG synthesis regulation involves activation of the PG synthesis enzyme system independent of phospholipase activity.

In the first series of experiments presented above we showed that PDGF stimulated $\mathrm{PGE}_{2}$ formation in the cell cycle of Swiss $3 \mathrm{~T} 3$ cells at two distinct time intervals: a first increase that was complete within $10 \mathrm{~min}$ and a second increase that occurred between 2 and $4 \mathrm{~h}$. These results confirmed and extended the findings of Shier (28) and Coughlin et al. (20) who showed that PDGF stimulates PG synthesis in cultured cells.

Our results using exogenous AA (Figs. 2 and 3, Table II) suggested that PDGF stimulated PG synthesis by mechanisms that are independent of phospholipase; the effect of PDGF on $\mathrm{PGE}_{2}$ synthesis from exogenous AA did not appear to be due to the PDGF-dependent increase in the AA pool (Table I). Furthermore, quiescent cells incubated with concentrations of $\mathrm{AA}$ as high as $16 \mu \mathrm{M}$ (Fig. 2) were unable to synthesize significant amounts of $\mathrm{PGE}_{2}$ although $\mathrm{AA}$ was taken up by the cells.

To gain further insight into the mechanism of PDGFdependent $\mathrm{PGE}_{2}$ synthesis stimulation from both endogenous and exogenous $\mathrm{AA}$, we next determined whether other cyclooxygenase products were stimulated by PDGF. The results presented in Fig. 4 demonstrate that PDGF stimulated 6-keto$\mathrm{PGF}_{1 \alpha}$ synthesis from both endogenous and exogenous AA and other experiments revealed similar effects of the growth factor on $\mathrm{TXB}_{2}$ and $\mathrm{PGF}_{2 \alpha}$ synthesis (results not shown). Since the effect of PDGF on stimulation of PG synthesis from exogenous $\mathrm{AA}$ included all of the major cyclooxygenasederived products, i.e., $\mathrm{PGE}_{2}$, 6-keto-PGF $\mathrm{PG}_{1 \alpha}, \mathrm{TXB}_{2}$, and $\mathrm{PGF}_{2 \alpha}$, these results suggest that the effect of PDGF was mediated by activation of the key enzyme of PG and TX synthesis, the cyclooxygenase.

In experiments using protein synthesis inhibition, we showed that the first increase in $\mathrm{PGE}_{2}$ synthesis from both endogenous and exogenous AA was protein synthesis independent while the second increase was completely suppressed in the presence of cycloheximide (Table II). The protein synthesis insensitivity of the first increase in $\mathrm{PGE}_{2}$ formation might, therefore, reflect rapid activation of the cyclooxygenase pathway by posttranslational modification mechanisms. Although these results are consistent with activation of the cyclooxygenase pathway, the mechanism of activation remains to be elucidated. It is possible that phosphorylation reactions are involved since PDGF has been shown to induce, within minutes, phosphorylation of several proteins (34).

The second increase of $\mathrm{PGE}_{2}$ synthesis observed between 2 and $4 \mathrm{~h}$ after stimulation of the cells was totally dependent on protein synthesis (Table II). To test whether protein synthesis was required for maintaining high $P G$ synthesis rates from exogenous $\mathrm{AA}$, we determined the kinetics of decline of $\mathrm{PGE}_{2}$ synthesis from exogenous AA in PDGF-stimulated cells (Fig. 5). The results show that protein synthesis inhibition resulted in rapid inactivation of the cyclooxygenase pathway with approximate half-maximal inhibition between 90 and $120 \mathrm{~min}$. This decline might reflect rapid turnover of enzymes involved in PG synthesis. The results are also consistent with rapid inactivation of the cyclooxygenase pathway as has been observed by Brotherton and Hoak (31) in cultured endothelial cells. In both cases, maintenance of high PG synthesis rates required translational activity.

The requirement for protein synthesis appeared to be closely associated with cyclooxygenase activity. Thus, quiescent cells pretreated with aspirin (Fig. 6) and stimulated by PDGF thereafter largely recovered during the protein synthesis-sensitive time period, i.e., between 2 and $4 \mathrm{~h}$. No significant recovery was observed during the first $2 \mathrm{~h}$ of the cell cycle. Furthermore, PDGF-stimulated cells that were incubated with aspirin, upon removal of aspirin, recovered from cyclooxygenase inhibition within $180 \mathrm{~min}$. In three independent experiments we observed that aspirin-treated cells, after recovery from cyclooxygenase inhibition, synthesized up to $45 \%$ more $\mathrm{PGE}_{2}$ from endogenous (not shown) and exogenous AA as compared with the control PDGF-stimulated cultures (Figs. 6 and 7). Since recovery from aspirin treatment was totally dependent on protein synthesis (results not shown), the enhanced PG synthesis rate after short-term inhibition with aspirin seemed to be due to enhanced de novo synthesis of cyclooxygenase after aspirin treatment. The mechanism underlying this phenomenon is presently unclear. Taken together, the results presented in Figs. 5-7 show that the PDGF-dependent stimulation of $\mathrm{PGE}_{2}$ occurring between 2 and $4 \mathrm{~h}$ is mediated by rapid de novo synthesis of cyclooxygenase.

In conclusion, our results disclose that PDGF has profound direct stimulatory effects on the PG synthesis system in addition to the earlier observed activation of the phospholipase $\mathrm{C}$ / diglyceride lipase pathway (14-16).

Recently, Bailey et al. (35) reported that epidermal growth factor shares some of the activities of PDGF. It will be of major general interest to determine whether activation of cyclooxygenase by agonists represents a general mechanism of PG biosynthesis regulation. If so, our results would have important implications for a variety of physiological as well as pathophysiological conditions. These include the response of tissues to hormones and the regulation of PG, leukotriene, and lipoxin biosynthesis in inflammatory diseases.

\section{Acknowledgments}

We are indebted to Mrs. A. Röttger for technical assistance in this study and to Mrs. B. Ungemach for typing of the manuscript.

This work was supported by the Deutsche Forschungsgemeinschaft grant HA 1083/2-2 and the Forschungsrat Rauchen und Gesundheit, Hamburg.

\section{References}

1. Hammarstrom, S. 1977. Prostaglandin production by normal and transformed 3T3 fibroblasts in culture. Eur. J. Biochem. 74:7-12.

2. Samuelsson, B., M. Goldyne, E. Granstrom, M. Hamberg, S. Hammarstrom, and C. Malmsten. 1978. Prostaglandins and thromboxanes. Ann. Rev. Biochem. 47:997-1029.

3. Rittenhouse-Simmons, S., and D. Deykin. 1981. Release and metabolism of arachidonate in human platelets. In Platelets in Biology and Pathology, Volume 2, J. C. Gordon, editor, Elsevier/North Holland Biomedical Press, Amsterdam. 349-371.

4. Michell, R. H. 1982. Inositol lipid metabolism in dividing and differentiating cells. Cell Calcium. 3:429-440.

5. Majerus, P. W. 1983. Arachidonate metabolism in vascular disorders. J. Clin. Invest. 72:1521-1525.

6. Irvine, R. F. 1982. How is the level of free arachidonic acid controlled in mammalian cells? Biochem. J. 204:3-16. 
7. Billah, M. M., E. G. Lapetina, and P. Cuatrecasas. 1981 Phospholipase $\mathrm{A}_{2}$ activity specific for phosphatidic acid-a possible mechanism for the production of arachidonic acid in platelets. J. Biol. Chem. 256:5399-5403.

8. Bills, T. K., J. B. Smith, and M. Silver. 1977. Selective release of arachidonic acid from the phospholipids of human platelets in response to thrombin. J. Clin. Invest. 60:1-6.

9. Hong, S. L., and D. Deykin. 1981. The activation of phosphatidylinositol-hydrolyzing phospholipase $\mathrm{A}_{2}$ during prostaglandin synthesis in transformed mouse BALB/3T3 cells. J. Biol. Chem. 256:52155219.

10. Michell, R. H., and C. J. Kirk. 1981. Why is phosphatidylinositol degraded in response to stimulation of certain receptors? Trends Pharmacol. Sci. 2:86-89.

11. Antoniades, H. N., and A. J. Queen. 1982. Growth factors and the regulation of cell growth. Ann. Rev. Med. 33:445-463.

12. Westermark, B., C. H. Heldin, B. Ek, A. Johnsson, K. Hellström, M. Nister, and A. Wasteson. 1983. Biochemistry and biology of platelet-derived growth factor. In Growth and Maturation Factors. H. Guroff, editors. Wiley, New York. 73-115.

13. Ross, R., and J. A. Glomset. 1979. Atherosclerosis and the arterial smooth muscle cell. Science (Wash. DC). 180:1332-1339.

14. Habenicht, A. J. R., J. A. Glomset, W. C. King, C. D. Mitchell, and R. Ross. 1981. Early changes in phosphatidylinositol and arachidonic acid metabolism in quiescent Swiss 3T3 cells stimulated to divide by platelet-derived growth factor. J. Biol. Chem. 256:1232912335 .

15. Habenicht, A. J. R., M. Goerig, J. Grulich, D. Rothe, R. Gronwald, G. Schettler, and B. Kommerell. 1984. The phospholipase $\mathrm{C} /$ diglyceride lipase pathway contributes to arachidonic acid (AA) release and prostaglandin (PG) $\mathrm{E}_{2}$ formation in platelet-derived growth factor (PDGF) stimulated Swiss 3 T3 cells. Adv. Prostaglandin Thromboxane Leukotriene Res. In press.

16. Habenicht, A. J. R., J. A. Glomset, M. Goerig, R. Gronwald, J. Grulich, U. Loth, and G. Schettler. 1985. Cell cycle-dependent changes in arachidonic acid and glycerol metabolism in Swiss 3T3 cells stimulated by platelet-derived growth factor. J. Biol. Chem. 260: 1370-1373.

17. Habenicht, A. J. R., J. A. Glomset, and R. Ross. 1980. Relation of cholesterol and mevalonic acid to the cell cycle in smooth muscle and Swiss 3T3 cells stimulated to divide by Platelet-Derived Growth Factor. J. Biol. Chem. 255:5134-5140.

18. Bell, R. L., D. A. Kennerly, N. Stanford, and P. W. Majerus. 1979. Diglyceride lipase: a pathway for arachidonate release from human platelets. Proc. Natl. Acad. Sci. USA. 76:3238-3241.

19. Majerus, P. W., S. M. Prescott, S. L. Hofman, E. J. Neufeld, and D. B. Wilson. 1983. Uptake and release of arachidonate by platelets. Adv. Prostaglandin Thromboxane Leukotriene Res. 11:4552.

20. Coughlin, S. R., M. A. Moskowitz, B. R. Zetter, H. N. Antoniades, and L. Levine. 1980. Platelet-dependent stimulation of prostacyclin synthesis by Platelet-Derived Growth Factor. Nature (Lond.). 288:600-602.

21. Rozengurt, E., P. Stroobant, M. D. Waterfield, T. F. Deuel, and M. Keehan. 1983. Platelet-Derived Growth Factor elicits cyclic AMP accumulation in Swiss 3T3 cells: role of prostaglandin production. Cell. 34:265-272.

22. Raines, E. W., and R. Ross. 1982. Platelet-derived growth factor. I. High yield purification and evidence for multiple forms. $J$. Biol. Chem. 257:5154-5160.

23. Granström, E., and H. Kindahl. 1978. Radioimmunoassay of prostaglandins and thromboxanes. Adv. Prostaglandin Thromboxane Res. 5:119-210.

24. Powell, W. S. 1982. Rapid extraction of arachidonic acid metabolites from biological samples using octadecylsilyl silica. Methods Enzymol. 86:467-477.

25. Hyman, B. T., L. L. Stoll, and A. A. Spector. 1982. Prostaglandin production by 3T3-L1 cells in culture. Biochim. Biophys. Acta. 713: 375-385.

26. Roth, G. J., N. Stanford, and P. W. Majerus. 1975. Acetylation of prostaglandin synthetase by aspirin. Proc. Natl. Acad. Sci. USA. 72: 3073-3076.

27. Flower, R. J., and G. J. Blackwell. 1979. Antiinflammatory steroids induce biosynthesis of a phospholipase A2 inhibitor which prevents prostaglandin generation. Nature (Lond.). 278:456-459.

28. Shier, W. T. 1980. Serum stimulation of phospholipase A2 and prostaglandin release in 3T3 cells is associated with platelet-derived growth promoting activity. Proc. Natl. Acad. Sci. USA. 77:137-141.

29. Michell, R. H. 1975. Inositol phospholipids and cell surface receptor function. Biochim. Biophys. Acta. 415:81-147.

30. Sawyer, S. T., and S. Cohen. 1981. Enhancement of calcium uptake and phosphatidylinositol turnover by Epidermal Growth Factor in A-431 cells. Biochemistry. 20:6280-6286.

31. Brotherton, A., and J. C. Hoak. 1983. Prostacyclin biosynthesis in cultured vascular endothelium is limited by deactivation of cyclooxygenase. J. Clin. Invest. 72:1255-1261.

32. Bonser, R. W., K. A. Chandrabose, and P. Cuatrecasas. 1980. Thrombin and bradykinin modulate prostaglandin synthetase independently of phospholipase. Adv. Prostaglandin Thromboxane Res. 6:259262.

33. Ogekawa, T., P. E. Jonas, K. De Schryver, A. Kawasaki, and P. Needleman. 1983. Metabolic and cellular alterations underlying the exaggerated renal prostaglandin and thromboxane synthesis in ureter obstruction in rabbits. Inflammatory response involving fibroblasts and mononuclear cells. J. Clin. Invest. 71:81-90.

34. Cooper, J. A., D. F. Bowen-Pope, E. Raines, R. Ross, and T. Hunter. 1982. Similar effects of platelet-derived growth factor and epidermal growth factor on the phosphorylation of tyrosine in cellular proteins. Cell. 31:263-273.

35. Bailey, J. M., B. Muza, T. Hla, and J. Pash. 1984. Role of epidermal growth factor (EGF) in synthesis of cyclooxygenase. Kyoto Conference on Prostaglandins, Kyoto, Japan. 52-3. (Abstr.) 